\title{
THE APPLICATION OF GIS-AHP TO DEVELOP A STRATEGIC PLANNING FOR AN URBAN FARMING: FISHERY AND AQUACULTURE
}

\author{
Bagiyo Suwasono* \\ Faculty of Engineering and Marine Science \\ Hang Tuah University \\ Surabaya 60111, Indonesia \\ E-mail: bagiyo.suwasono@hangtuah.ac.id \\ Nurul Rosana \\ Faculty of Engineering and Marine Science \\ Hang Tuah University \\ Surabaya 60111, Indonesia \\ E-mail: nurul.rosana@ hangtuah.ac.id
}

\begin{abstract}
The purpose of this study is the evaluation of strategic planning in developing an urban farming: program of fishery and aquaculture in Surabaya City $\left(7^{\circ} 9^{\prime}-7^{\circ} 21^{\prime}\right.$ south latitude and $112^{\circ} 36^{\prime}-112^{\circ} 57^{\prime}$ east longitude), Indonesian. It would be crucial for government's policy to understand the relative importance of various environmental factors. To support their decision in making process, a Geographic Information System (GIS) was combined with an Analytical Hierarchy Process (AHP) in this study. The GIS were produced through processing image data and map digitized by using Google Earth, ArcGIS and Spatial Plan of Surabaya city. Meanwhile, the data was used in designing development priorities Urban Farming: Fishery and Aquaculture by using the AHP approach. The result from an urban aquaculture can be utilized to develop the effective of strategies at paddy field, natural fish ponds, fish cages, and artificial fish ponds.
\end{abstract}

Keywords: GIS-AHP method, multi criteria, urban farming: fishery and aquaculture, strategic planning

\section{Introduction}

The study of urban farming is currently growing in relation to public health issues. It has the same issues to anticipate the problems of food security, flood, urban heat reduction, energy efficiency, air quality, climate change, habitat extinction, and prevention of crime (Mazeereuw, 2005). As a result of these circumstances the definition of urban farming was constantly evolving in a wide range of literature review (Smit, 1996; FAO, 1999; Nugent, 2000; Bailkey and Nasr, 2000; Baumgartner and Belevi, 2007). A simple definition of urban farming was a farmer, processing and distribution of various food commodities, including vegetables and livestock in the urban areas.

Based on the definition of urban farming; Surabaya city was officially founded in 1293, and known as a port city in the services and trades. The urban farming program is used by Surabaya city in the early years 2011. Surabaya city was the strategic line that connects regional in Central and eastern Indonesia. Geographically located in $7^{\circ} 9^{\prime}-7^{\circ} 21^{\prime}$ South latitude and $112^{\circ} 36^{\prime}-112^{\circ} 57^{\prime}$ East longitude. The

\footnotetext{
${ }^{*}$ Corresponding author
} 
majority of topography from Surabaya city was the lowlands by the height of 3-6 meters above sea level, and a southern side a hilly region with an altitude of 25-50 meters above sea level.

The total area of Surabaya city was 52.087 hectares, by mainland 33,048 hectares $(63,45 \%)$ and sea 19,039 hectares $(36,55 \%)$. Sub-Districts in Surabaya city have agricultural potential of limited land, like Kenjeran, Bulak, Wiyung, Jambangan, Lakarsantri, Sambikerep, Benowo, and Tandes. The potential farm businesses are still relying on dairy cow milk and livestock products such as poultry and goats. As the continuity of the agricultural sector in the future, Surabaya city will depend on the areas of fisheries, aquaculture, and fish catching shown in Table 1.

Table 1. Agricultural Sector

\begin{tabular}{|l|r|}
\hline \multicolumn{1}{|c|}{ Sector } & IDR (In Billion Rupiah) \\
\hline Agricultural & 58,96 \\
\hline 1. Plant Food Ingredients & 6,32 \\
\hline 2. Plantation & 0,00 \\
\hline 3. Livestock & 2,78 \\
\hline 4. Forestry & 0,00 \\
\hline 5. Fishery & 49,86 \\
\hline
\end{tabular}

Source: Statistical Surabaya City, 2010

\section{Methodology}

\subsection{Identification of Region}

Plan of the region based on Urban Farming: Fishery \& Aquaculture by using Google Earth, ArcGIS and Spatial Plan from Surabaya city. The structure plan area of the sea is divided into the 4 zone of development based on condition, characteristics and potential of the region by sea. While the study area for the development of Urban Farming: Fishery and Aquaculture, covers 10 sub-districts mainland and 21 sub-districts coastal (intrusion of sea and coastal-sea), as shown in Table 2.

Table 2. Plan of Region on Urban Farming: Fishery and Aquaculture

\begin{tabular}{|c|c|c|c|c|c|c|}
\hline No & $\begin{array}{c}\text { Sub-District } \\
\text { Mainland }\end{array}$ & $\begin{array}{c}\text { Intensiveness } \\
\text { Person/Ha }\end{array}$ & $\begin{array}{c}\text { Sub-District } \\
\text { Intrusion of Sea }\end{array}$ & $\begin{array}{c}\text { Intensiveness } \\
\text { Person/Ha }\end{array}$ & $\begin{array}{c}\text { Sub-District } \\
\text { Coastal \& Sea }\end{array}$ & $\begin{array}{c}\text { Intensiveness } \\
\text { Person/Ha }^{*}\end{array}$ \\
\hline 1 & Sambikerep & 38,07 & Pakal & 24,93 & Benowo & 20,21 \\
\hline 2 & Lakar Santri & 25,06 & Tandes & 93,23 & Asemrowo & 27,66 \\
\hline 3 & Wiyung & 54,58 & Suko Manunggal & 109,01 & Krembangan & 127,87 \\
\hline 4 & Dukuh Pakis & 64,67 & Sawahan & 246,22 & Pabean Cantikan & 102,16 \\
\hline 5 & Karang Pilang & 78,55 & Bubutan & 218,67 & Semampir & 172,72 \\
\hline 6 & Jambangan & 110,91 & Tambaksari & 227,66 & Kenjeran & 213,92 \\
\hline 7 & Gayungan & 70,34 & Gubeng & 160,18 & Bulak & 54,93 \\
\hline 8 & Simokerto & 306,51 & Wonokromo & 157,35 & Mulyorejo & 66,65 \\
\hline 9 & Genteng & 115,00 & Wonocolo & 118,38 & Sukolilo & 50,62 \\
\hline 10 & Tegalsari & 199,37 & Tenggilis Mejoyo & 131,21 & Rungkut & 57,44 \\
\hline 11 & \multicolumn{7}{|l|}{} & Average & 148,68 & Average & 87,77 \\
\hline
\end{tabular}

* $\mathrm{Ha}=$ hectare

Source: Suwasono \& Rosana, 2012; Statistical Surabaya City, 2010* 


\subsection{Processing and Analysis Data}

Processing image data and map digitized using Google Earth, ArcGIS and Spatial Plan from Surabaya city, as shown in Figure 1.

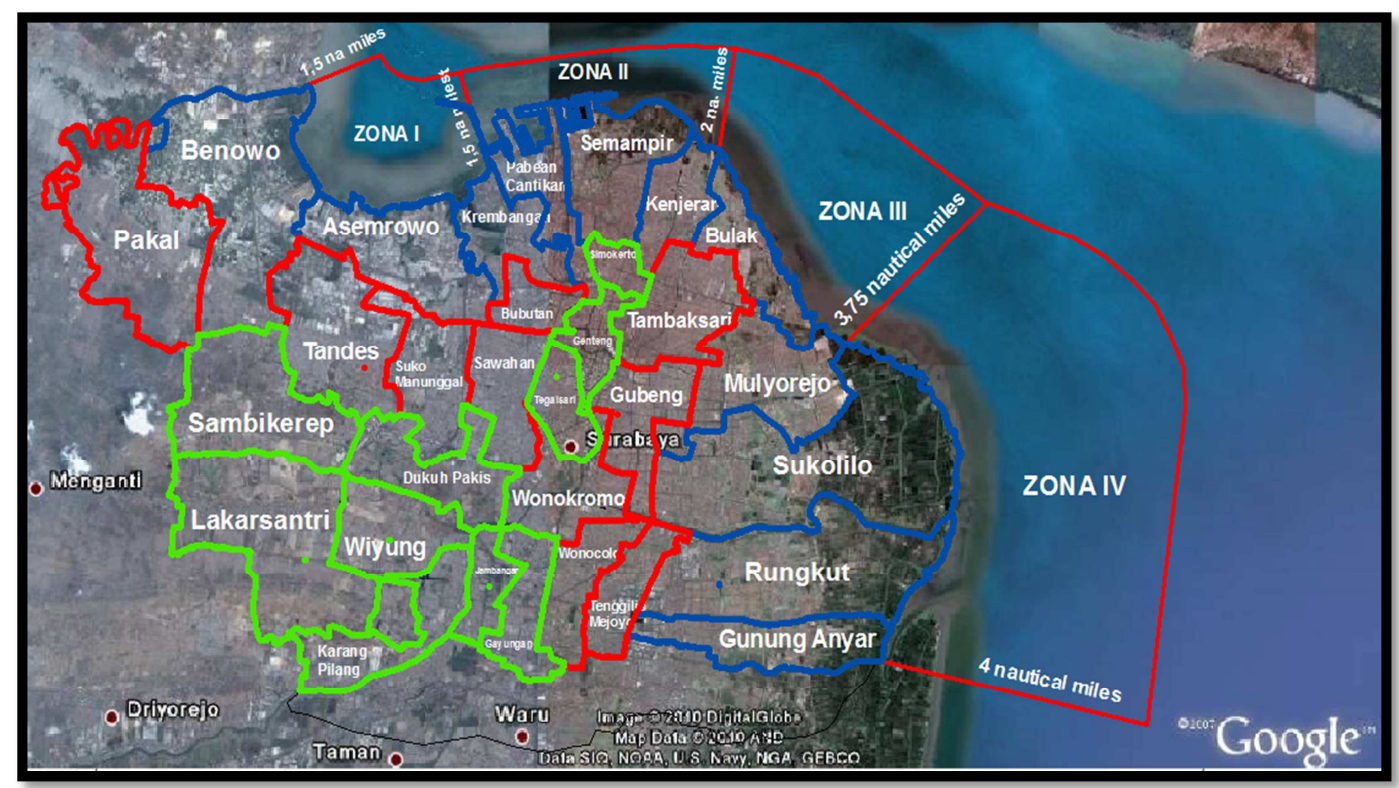

Figure 1. Plan of Region based ArcGIS on Urban Farming: Fishery \& Aquaculture Source: Suwasono \& Rosana, 2012

Information results of GIS analysis in the form of a suitable location for each designation was used as input real to obstacle factor. The data used in designing development priorities Urban Farming: Fishery and Aquaculture using Analytical Hierarchy Process (AHP) as shown in Figure 2. The stages in the AHP by Saaty (1988) are an identification system, preparation of hierarchy, pair wise comparison matrix, individual opinion, opinion matrix composite processing, horizontal, vertical processing, and revise opinion.

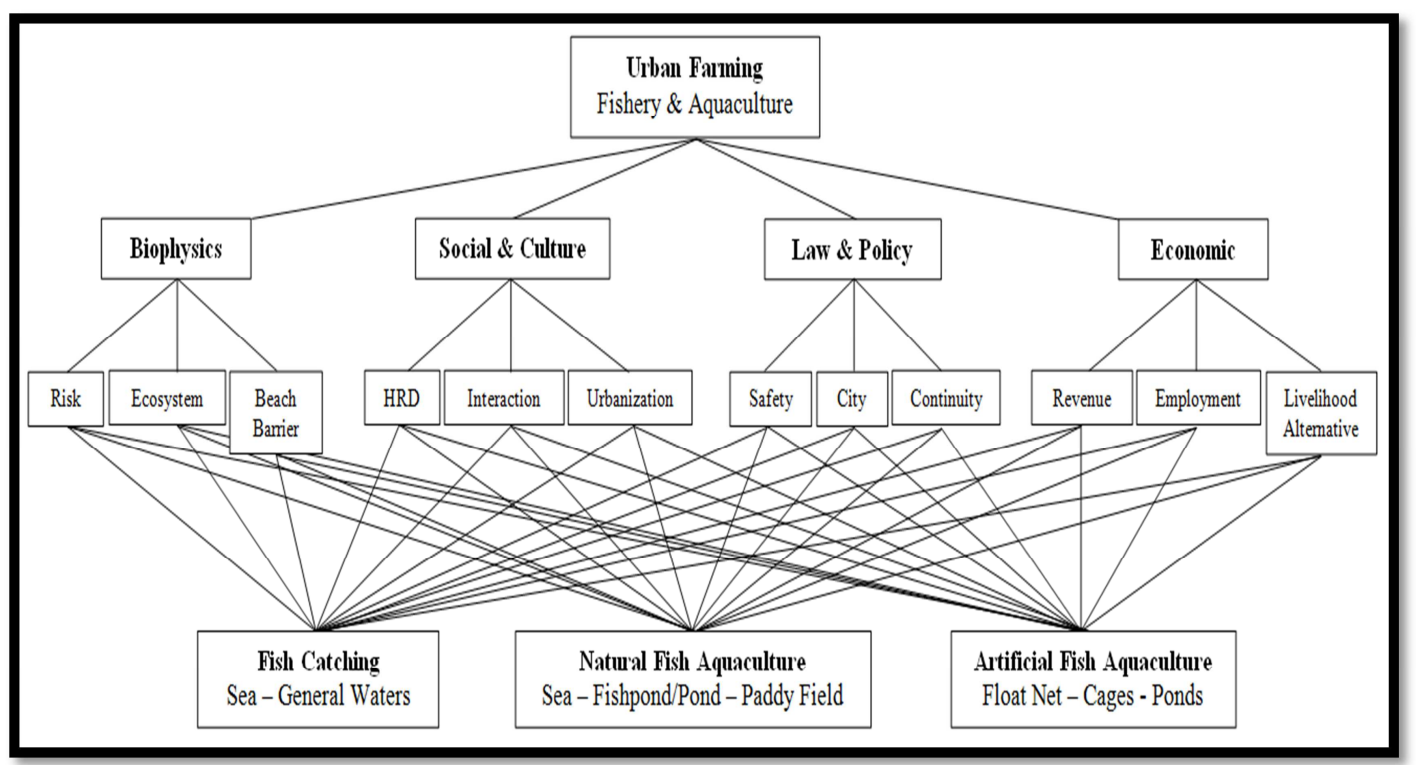

Figure 2. AHP Schematic for Urban Farming: Fishery \& Aquaculture 


\section{Result and Discussion}

\subsection{Resources of Fishery and Aquaculture}

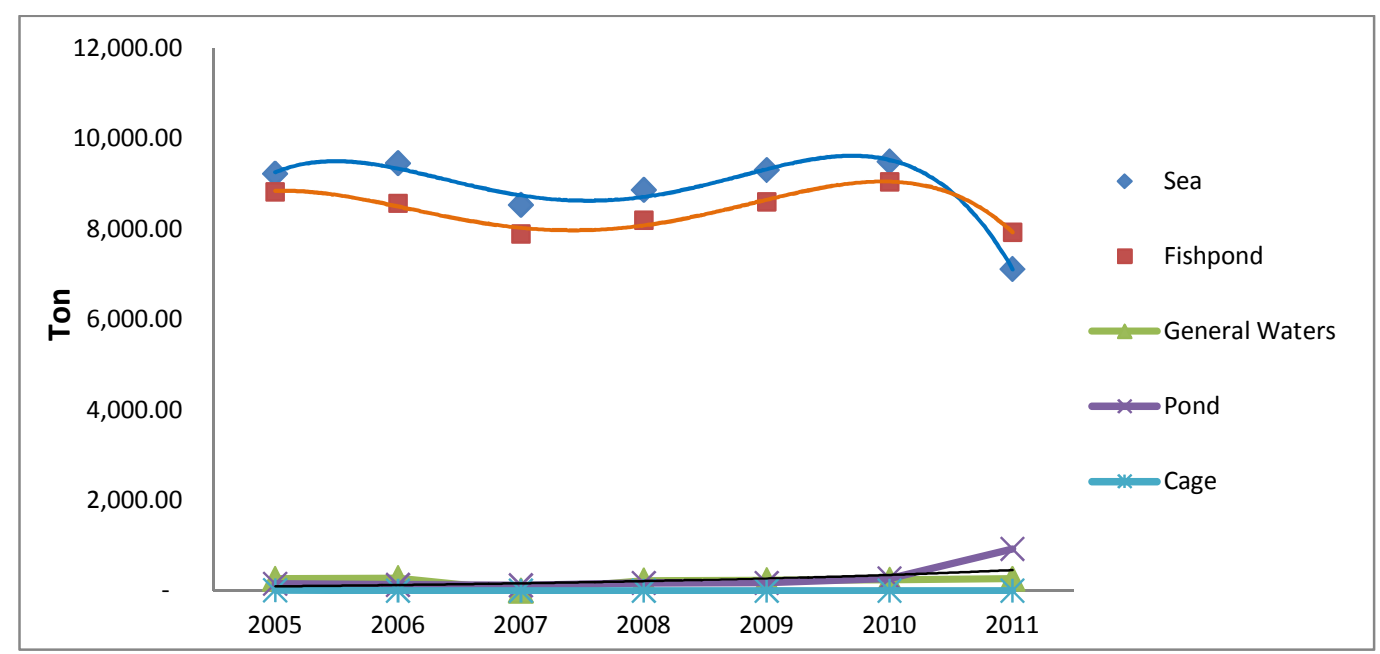

Figure 3. Time Series from Resources of Fishery and Aquaculture Source: Surabaya City Agriculture Office

The average from fisheries result of Surabaya city for 6 years $\geq 7,500$ tons, ie: catching and fishpond. While fish products from general waters, and cages $\leq 1,000$ tons. On the other hand the product of fish cages has decreased was not developed further. So overall number of fishery production conditions the city of Surabaya has a declining trend fluctuations. This provides an indication of declining in fish stocks, so it required a variety of joint efforts for recondition biodiversity resource through a variety of technology approach to natural conservation, and a continuous coordination for the management of biological resources (Madura - Surabaya - Sidoarjo - Pasuruan).

\subsection{Analytical Hierarchy Process (AHP)}

Table 3. End Priorities of Urban Farming: Fishery \& Aquaculture - The Sub-District: Land

\begin{tabular}{|c|c|c|c|c|c|}
\hline \multirow{2}{*}{$\begin{array}{c}\text { Infrastructure } \\
\text { Technology }\end{array}$} & Biophysics & Social - Cultural & Law \& Policy & Economic & \multirow{2}{*}{$\begin{array}{c}\text { End } \\
\text { Priorities }\end{array}$} \\
\cline { 2 - 5 } Catching & 0.08427 & 0.173225118 & 0.037685377 & 0.7048224 & 0.066227763 \\
\hline Natural Aquaculture & 0.06731 & 0.065112812 & 0.075229328 & 0.0701498 & 0.57026 \\
\hline Artificial Aquaculture & 0.30363 & 0.570001373 & 0.241308075 & 0.2043343 & 0.545096064 \\
\hline
\end{tabular}

Percentage of management factors of urban farming in land sub-district:
a. Influences of economic stability $=70.48 \%$
b. Influences of social - cultural $=17.32 \%$
c. Influences of biophysics $=8.43 \%$
d. Influences of Law and Policy $=3.77 \%$.

Priorities of development program fishery \& aquaculture:

a. Natural aquaculture (fishpond \& paddy field) $=54.51 \%$

b. Artificial aquaculture (float net, cage $\&$ pond) $=34.40 \%$

c. Catching (general waters) $=6.62 \%$. 
Table 4. End Priorities of Urban Farming: Fishery \& Aquaculture - The Sub-District: Intrusion of Sea

\begin{tabular}{|c|c|c|c|c|c|}
\hline \multirow{2}{*}{$\begin{array}{c}\text { Infrastructure } \\
\text { Technology }\end{array}$} & Biophysics & Social - Cultural & Law \& Policy & Economic & \multirow{2}{*}{$\begin{array}{c}\text { End } \\
\text { Priorities }\end{array}$} \\
\hline & 0.06479 & 0.186447806 & 0.031515431 & 0.7172515 & \\
\hline Catching & 0.09662 & 0.091820267 & 0.080507128 & 0.0880758 & 0.094087225 \\
\hline Natural Aquaculture & 0.19847 & 0.177148101 & 0.228141538 & 0.1805938 & 0.197044956 \\
\hline Artificial Aquaculture & 0.72014 & 0.715836378 & 0.665784904 & 0.7185937 & 0.713989764 \\
\hline
\end{tabular}

Percentage of management factors of urban farming in land sub-district:

a. Influences of economic stability $=71.73 \%$

b. Influences of social - cultural $=18.64 \%$

c. Influences of biophysics $=6.48 \%$

d. Influences of Law and Policy $=3.15 \%$.

Priorities of development program fishery $\&$ aquaculture:

a. Natural aquaculture (fishpond \& paddy field) $=71.40 \%$

b. Artificial aquaculture (float net, cage $\&$ pond) $=19.70 \%$

c. Catching (general waters) $=9.41 \%$.

Table 5. End Priorities of Urban Farming: Fishery \& Aquaculture - The Sub-District: Coastal and Sea

\begin{tabular}{|c|c|c|c|c|c|}
\hline \multirow{2}{*}{$\begin{array}{l}\text { Infrastructure } \\
\text { Technology }\end{array}$} & Biophysics & Social - Cultural & Law \& Policy & Economic & \multirow{2}{*}{$\begin{array}{c}\text { End } \\
\text { Priorities }\end{array}$} \\
\hline & 0.58044 & 0.102170727 & 0.067023645 & 0.2503638 & \\
\hline Catching & 0.21939 & 0.225792629 & 0.078511595 & 0.1107913 & 0.189451618 \\
\hline Natural Aquaculture & 0.50299 & 0.516163353 & 0.217634217 & 0.2095316 & 0.442488421 \\
\hline Artificial Aquaculture & 0.20201 & 0.2395798 & 0.68075486 & 0.6917548 & 0.344513585 \\
\hline
\end{tabular}

Percentage of management factors of urban farming in land sub-district:

a. Influences of economic stability $=58.04 \%$

b. Influences of social - cultural $=25.04 \%$

c. Influences of biophysics $=10.22 \%$

d. Influences of Law and Policy $=6.70 \%$.

Priorities of development program fishery \& aquaculture:

a. Natural aquaculture (sea \& fishpond) $=44.25 \%$

b. Artificial aquaculture (float net, \& cage) $=34.45 \%$

c. Catching (sea) $=18.95 \%$.

Based on the AHP by three different sub-districts as shown in Table 3 till 5 , is obtained contribution factor of the biggest management from urban farming is the effect of economic stability and social culture. While the development priority program in fishery and aquaculture were natural aquaculture and artificial aquaculture. Summary of the planning priorities for the development of urban farming: fishery and aquaculture as shown in Table 6. 
Table 6. Priorities of Development Plan in Urban Farming: Fishery \& Aquaculture

\begin{tabular}{|c|c|c|c|c|c|}
\hline \multirow{2}{*}{$\begin{array}{l}\text { Fishery and } \\
\text { Aquaculture }\end{array}$} & \multicolumn{3}{|c|}{ Sub-District (\%) } & \multirow{2}{*}{ Value } & \multirow{2}{*}{ Description } \\
\hline & Land & Intrusion of Sea & Coastal \& Sea & & \\
\hline \multicolumn{6}{|c|}{ Management Factor } \\
\hline 1. Economic & 70,48 & 71,73 & 25,04 & 167,25 & - Revenue \\
\hline 2. Biophysics & 8,43 & 6,48 & 58,04 & 72,95 & $\begin{array}{l}\text { - ecosystem } \\
\text { - Risk }\end{array}$ \\
\hline $\begin{array}{l}\text { 3. Social } \\
\text { Culture }\end{array}$ & 17,32 & 18,64 & 10,22 & 46,18 & $\begin{array}{l}\text { - HRD } \\
\text { - Urbanization }\end{array}$ \\
\hline $\begin{array}{l}\text { 4. Law \& } \\
\text { Policy }\end{array}$ & 3,77 & 3,15 & 6,70 & 13,62 & - Policy \\
\hline \multicolumn{6}{|c|}{ Program Development } \\
\hline $\begin{array}{l}\text { 1. Natural } \\
\text { Aquaculture }\end{array}$ & 54,51 & 71,73 & 44,25 & 170,49 & $\begin{array}{l}\text { - Paddy field } \\
\text { - Fishpond/Pond } \\
\text { - Sea (contamination) }\end{array}$ \\
\hline $\begin{array}{l}\text { 2. Artificial } \\
\text { Aquaculture }\end{array}$ & 34,40 & 19,70 & 34,45 & 88,55 & $\begin{array}{l}\text { - Pond } \\
\text { - Cage } \\
\text { - Float net (uncertainty risk) }\end{array}$ \\
\hline $\begin{array}{l}\text { 3. Fish } \\
\text { Catching }\end{array}$ & 6,62 & 9,41 & 18,95 & 34.98 & $\begin{array}{l}\text { - General waters (contamination) } \\
\text { - Sea (one day fishing) }\end{array}$ \\
\hline
\end{tabular}

Based on the mapping of Surabaya city and hierarchy process, then development priorities obtained urban aquaculture focused on natural aquaculture (paddy fields and fishpond) and artificial aquaculture (pond and cage). The main indicators from a success program are economic (revenue), Biophysics (ecosystem and risk), and social-cultural (human resources and urbanization).

3.3 Implication of Program

Table 7. Indicator Economic from Catfish Aquaculture 2011 - 2012

\begin{tabular}{|c|c|c|c|c|c|}
\hline \multirow{2}{*}{$\begin{array}{c}\text { Catfish } \\
\text { per month }\end{array}$} & \multicolumn{4}{|c|}{ Sub-District } & \multirow{2}{*}{ Pattern Mapping } \\
\hline & Mainland & Intrusion of Sea & Coastal \& Sea & Total & \\
\hline \pm 5 millions & 2 & 4 & 3 & 9 & Centre \\
\hline \pm 10 millions & 2 & 2 & 2 & 6 & \multirow{4}{*}{ Spread } \\
\hline \pm 15 millions & 1 & 1 & 4 & 6 & \\
\hline \pm 20 millions & 2 & 0 & 1 & 3 & \\
\hline \pm 25 millions & 1 & 1 & 0 & 2 & \\
\hline \pm 50 millions & $\begin{array}{c}\mathbf{2} \\
\text { Sambikerep } \\
\text { Lakasantri }\end{array}$ & $\begin{array}{c}\mathbf{2} \\
\text { Pakal } \\
\text { Tandes }\end{array}$ & $\begin{array}{c}1 \\
\text { Benowo }\end{array}$ & 5 & West \\
\hline Sum & 10 & 10 & 11 & 31 & \\
\hline
\end{tabular}

Table 7 showed that based on indicators of economic factors and mapping studies in assessment program, then the catfish aquaculture development focus are retained at sub-districts mainland with distribution pattern to westward. 


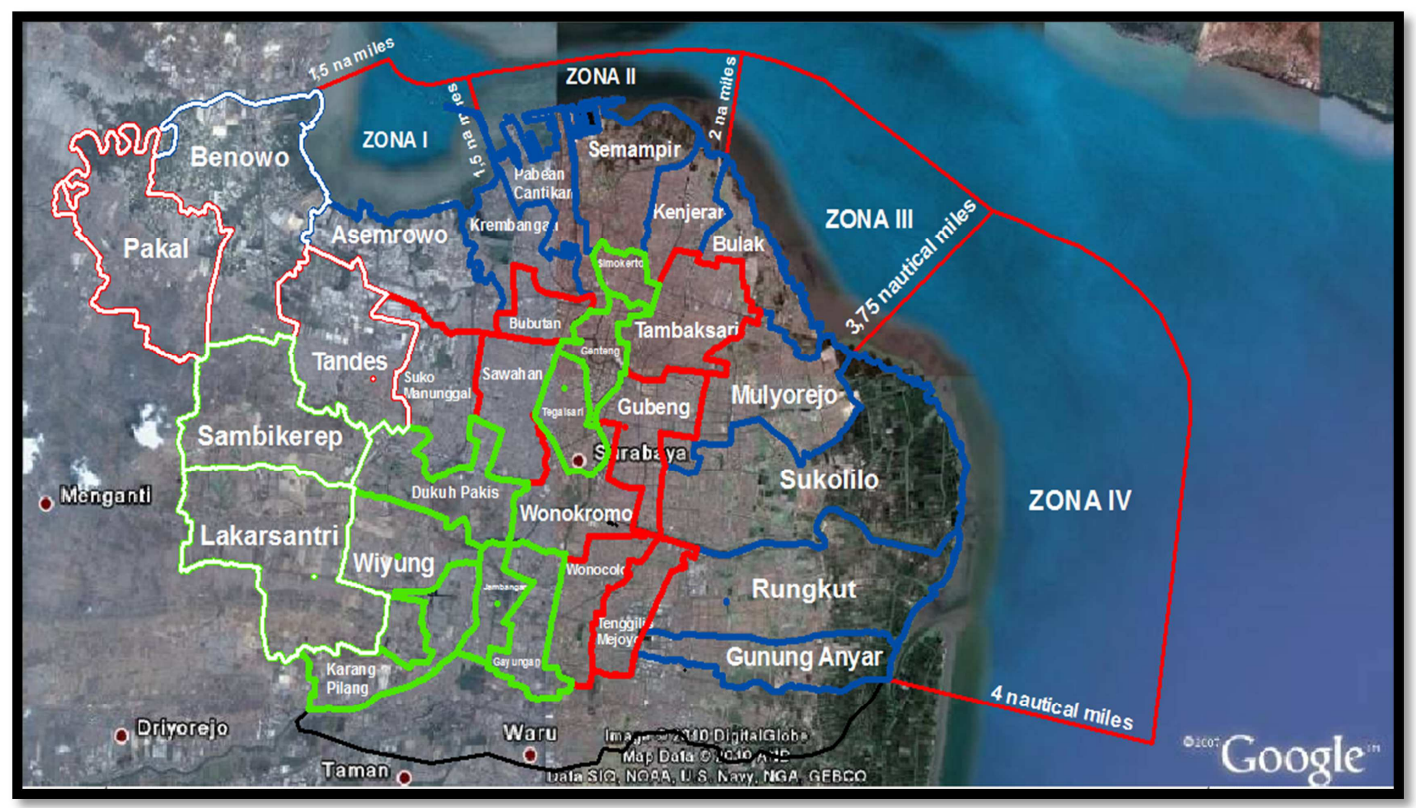

Figure 4. Catfish Aquaculture with the Pattern of a West Side

\section{Conclusion}

The Strategic planning for an urban farming using GIS was focused on the development of:

- An aquaculture program in Surabaya city was based on the condition, characteristics and potential of mainland (10 sub-districts), intrusion of sea water (10 sub-districts), or coast - sea (11 sub-districts).

- Natural aquaculture (fishpond and paddy field) and artificial aquaculture (pond and cage) have succeed indicators on economic (income), biophysics (ecosystem and risk), and social-cultural (human resources and urbanization).

- Catfish aquaculture was running at sub-districts with the distribution pattern of the Mainland to the West side.

\section{REFERENCES}

ArcGIS. (1999 - 2008). AcrMap ${ }^{T M}$ 9.3. ESRI, New York, Amerika.

Bailkey, M., \& Nasr, J. (2000). From Brownfields to Greenfields: Producing Food in North Americancities. Community Food Security News, Fall 1999/Winter 2000:6.

Baumgartner, N., \& Belevi, H. (2007). A Systematic Overview of Urban Agriculture in Developing Countries. AWAG - Swiss Federal Institute for Environmental Science \& Technology. SANDEC - Dept. of Water \& Sanitation in Developing Countries.

Food and Agriculture Organization. (1999). FAO Press Releases. The United Nations.

Mazeereuw, B. (2005). Urban Agriculture Report. Region of Waterloo. Public Health.

Nugent, R. (2000). The Impact of Urban Agriculture on the Household and Local Economies. In: Growing Cities. Growing Food (Ed.: N. Bakker, M. Dubbeling, S. Gündel, U. Sabel-Koschella and H. de Zeeuw), DSA, Eurasburg, 76-97. 
Smit, J. (1996). Urban Agriculture - Food, Jobs and Sustainable Cities. United Nations Development Program, New York.

Saaty, T.L. (1988). The Analytical Hierarchy Process. University of Pittsburgh, United States of America.

Suwasono, B., \& Rosana, N. (2012). Urban Farming Study: Fisheries and Aquaculture on Region of Surabaya City. Final Report. Department of Citizen Welfare, Agency of City Development Planning, Surabaya. 